\title{
The Need Analysis of Student Worksheet for Writing Drama Script of Seventh Grade Student
}

\author{
Desi Efrina Simbolon ${ }^{1 *}$, Sri Indrawati ${ }^{2}$, Ernalida $^{3}$ iD \\ ${ }^{1}$ Postgraduate Student of Universitas Sriwijaya, Indonesia \\ ${ }^{2,3}$ The lecturers of Universitas Sriwijaya, Indonesia \\ *Corresponding author: desyeff@gmail.com
}

\begin{abstract}
This research aims to describe the results of the learners' needs toward the drama script writing material development using a scientific approach. This research applied a qualitative approach. The data were collected with observation, questionnaire, and interview techniques. The applied instruments were observation, questionnaire, and interview. The sample consisted of learners. The findings showed that the learners needed communication and technology-based teaching materials to support their needs of drama script writing skill training. Based on the learners' characteristics identification, they needed learning application to make the learning activities and to freely enrich the sources. They also needed interesting teaching materials that had many examples, provided writing exercises, the opportunity to interact, time to work the exercise, and space to perform. Therefore, this research proposed Moodle application as a learning material in the form of a Student Worksheet. This initial stage of research is expected to be the beginning of drama script writing material development with a scientific approach and based on Moodle. The results of the learners' need analysis could be also used by other researchers to obtain the 21 st-century learners' characteristics.
\end{abstract}

Keywords: Need Analysis, Script Writing

$\begin{array}{ll}\text { History: } & \\ \text { Received } & : 4 \text { January } 2021 \\ \text { Revised } & : 16 \text { February } 2021 \\ \text { Accepted } & : 6 \text { March } 2021 \\ \text { Published } & : 25 \text { April } 2021\end{array}$

\section{Introduction}

Learning is a set of arranged materials by teachers to facilitate teaching-learning activities. Lack of proper teaching materials could influence the learning quality (Khaerudin, Kusmana, \& Khaerudin, 2019; Suryani \& Rasdawita, 2018). Teaching materials are all applied materials to facilitate teachers or instructors in promoting teaching-learning activities. Teaching materials require development to realize effective and efficient learning that sticks to the targeted competence. Teaching materials are defined as a tool to facilitate learners in learning a certain competence or basic competence. Thus, they could master all the competencies completely. Teaching materials essentially consist of lessons or courses given for the learners with the applied curriculum (Wardani, Alwi, \& Hakim, 2020). Teaching materials should be complete and systematic to improve the learners' skills. The prepared teaching materials are expected to improve the learners' understanding of the given materials. They could be realized into written or non-written materials.

Writing skill for Junior High School learners is something difficult for them. Most learners argued that they had difficulties getting the ideas or notions for writing scientifically. It requires teachers' skills to support the learning process to make learners interested in 
writing. One of them is by applying appropriate learning material (Khaerudin et al., 2019; Setyowati \& Sukmawan, 2019).

According to the syllabus of the Indonesian language lesson for seventh graders of Islamic Senior or Senior High School levels, 2013 curriculum, learners must be able to present drama at a stage or on a script. The achievement indicator of this research was drama script. Drama scriptwriting is an imaginative thinking activity to produce a complete and systematic art. It is begun with determining the themes, creating the storyline, determining the characters, patterns, and scenes, and developing the dialog. Then, a complete and systematic drama script could be realized. Writing a drama script is not an easy matter moreover for Senior High School learners. Therefore, studies on learning media selection are needed to make learners' creative thinking processes. It is important, especially within the 2013 curriculum. It demands the scientific approach. The applied learning process is done by observing, questioning, collecting information, associating, and communicating. The scientific approach is a learning model with scientific principles. It consists of data collection activities by observing, questioning, experimenting, processing the information or data, and communicating.

The scientific approach is designed to activate learners in constructing the concepts, laws, and principles by observing (to identify or determine the problems), formulating the problems, posting or formulating hypotheses, collecting data with various techniques, analyzing the data, drawing the conclusions, and communicating the concepts, laws, and the obtained principles (Wardani et al., 2020). The scientific approach motivates learners to be active during the learning process and to construct knowledge and skills. Those reasons made the researchers aimed to describe the need analysis results of the learners toward the drama script writing material development with a scientific approach. Teaching materials could be in the form of objects of persons to facilitate the learning process. Teaching materials, such as textbooks, assignments, and supplementary could facilitate, motivate, build, and improve learning activities.

The applied teaching materials during the learning process should be developed based on the learners' needs (Murti \& Muhtadin, 2019). Teaching materials mediate the knowledge-delivery process and skills from the teachers or presenters toward learners. Learning material development cannot be separated from learning activities. It functions as the implementation to reach the applied learning objects. Teaching materials functioned as a reference to support the learners' development so that their physical and religious needs could be balanced. A complete and systematic learning material could motivate learners to learn, facilitate the learning process, and motivate them to learn. Appropriate learning material selection would facilitate both teachers and instructors to optimize the learning outcomes. It would eventually facilitate learners to master the competence and learning objectives.

Teaching materials were an important factor of effective learning in higher education. Lack of teaching materials influenced learning quality or college. There are some functions in arranging teaching materials as considerations. They are the important guidelines for teachers and learners, and achievement evaluation during the learning process. Various teaching materials could be used to facilitate learners to master the competencies. All applied teaching materials to support teaching materials could be categorized into printed, audio, audio-visual, and interactive multimedia teaching materials. They should consider the teaching material principles while selecting the appropriate materials. This study was carried out in the seventh grade of Public Junior High School 17 Palembang. It was done based on the observation and interview on March 16, 2020. The teacher of the class stated that both teacher and learners still had difficulties in understanding drama script writing materials. 
Some previous studies related to drama scriptwriting were done by Aji et al (2017), Khaerudin et al (2019), Murti \& Muhtadin (2019), and Suryani \& Rasdawita (2018). They conducted research and development to create teaching materials for both learners and college students. The researchers applied different research and development methods, such as ADDIE, Dicky and Carey, and ASSURE models. All studies were done until the validation and mass production of the products. The previous studies were different from the current research. They could be seen from the gaps between the previous studies and current research. They were such as the applied R\&D model, the subject and object of the research, and the different learners' needs on the previous study and current study.

Thus, from the gaps, this research aimed to analyze the learners' needs toward drama script teaching material development with a scientific approach. After reviewing the applied research and development models of the previous studies, the researchers found that the models had not been able to answer the researchers' expectations. Based on the research objectives, the learners' need analysis did not only answer the needed matters, the extension of the development, and the targeted achievement. Therefore, the researchers sought other appropriate research and development model.

\section{Materials and Methods}

The applied research and development model was Allessi and Trollip's model. This model is specialized to develop learning media. The model phases consist of planning, designing, and developing. Some studies had applied the research and development model, such as Admadja \& Marpanaji (2016), and Yogiyatno \& Sofyan (2013). The research model was suitable for the research and development because it fitted on developing teaching materials, media, and novice researchers (Yogiyatno \& Sofyan, 2013). This research is expected to contribute theoretically and practically. Theoretically, this research's findings could facilitate understanding the concepts of theories and enrich research and development literature and references about writing teaching materials, specifically writing a drama script.

They were in line with the objectives of this research, to analyze the learners' needs toward the drama script writing material development with a scientific approach. Therefore, this research was carried out qualitatively. The stages consisted of: determining the scope, identifying the learners' characteristics, determining and collecting the resources, and brainstorming. The stages were done by collecting the data via observations, questionnaires, and interviews.

This research was carried out in Public Junior High School 17 Palembang, Padang Selasa street, Bukit Lama, Ilir Bar district, Palembang, Southern Sumatra. The subjects consisted of the Indonesian language teachers at the seventh grade and 240 - seventh graders of the school. The applied data analysis technique was the descriptive technique. The collected data were not used separately instead they were supporting each other. The observation was done first to find out the preliminary condition. It was done to ensure the other instrument could be applied, the questionnaire. The questionnaire results were analyzed, checked, classified objectively, described, and concluded to find out the information about drama scriptwriting teaching materials development with a scientific approach.

On the other hand, the interview results with the teacher and the learners were used as the initial data for the research background and as supplementary data. The interview results were summarized objectively, described, and concluded to complete the teaching material need identification data with a scientific approach. 


\section{Results and Discussion \\ Results}

The results showed that the Indonesian language lesson in the second semester of the grade applied the 2013 curriculum. Based on the questionnaire result on question number two, learners did not consider the applied teaching materials were excellent because the explanation and the reading were not interesting; the information and the examples were limited, and; there was no new information. From the questionnaire, the third question item, the learners needed various information in the form of audio, videos, and figures. The fourth question was answered based on the learners' expectations toward the developed teaching materials. From the questionnaire, the learners wanted the teaching materials were not limited to textbooks.

The learners were demanded to be able to present a drama on a stage or written script. The researchers observed the research location. The results showed that during the learning process, the applied teaching materials were the Indonesian language textbook published by the Ministry of Education and Culture of Republic Indonesia, 2017, with the 2013 curriculum, and the student worksheet given by the government. Studies by Asrowi et al (2019) and Behnke (2018) showed that textbooks influenced teaching and learning and also their interaction.

From the findings, the researchers followed up the results by interviewing the teacher of the lesson. The teacher admitted the limitation of teaching materials caused the learners to have difficulties developing ideas while writing. This finding was also in line with Anh, (2019) and Uba \& Souidi (2020). They found that the subjects of the studies could not develop ideas due to a lack of vocabulary. In this research, the teacher also admitted that the applied learning was not interesting for the learners so they were easily bored with the materials. Thus, the applied teaching materials were not appropriate for the learners. Zagorskis et al (2019) suggested that teachers should find a solution for learners' boredom.

Teaching materials could improve the learners' learning outcome, motivate them to learn continuously, improve their content and material retention, and make them actively participating to apply the knowledge and skills. Studies by Amin (2018), Andrajati et al (2020), Cintang (2019) Hakim \& Wati (2019), and Setyowati \& Sukmawan (2019) also showed that learners needed innovative and practical teaching materials to improve their skills and construct their knowledge.

From this point, the researchers followed up by distributing the questionnaire. The first question of the questionnaire elicited their arguments about the applied teaching materials. There were six themes based on the answers. The following table shows the learners' responses to the question.

Table 1. The learners' responses toward the applied teaching material

\begin{tabular}{cc}
\hline The Theme Category & Percentage \\
\hline Excellent & $22 \%$ \\
Limited & $8 \%$ \\
Average & $12 \%$ \\
Not simple & $22 \%$ \\
Boring & $23 \%$ \\
\hline
\end{tabular}

From Table 1, the researchers could determine the scope to analyze the learners' needs. The indications showed that the applied teaching materials could not make the learners actively learned. 


\section{Discussion}

The Learners' Characteristic Identifications

The findings from the second question of the questionnaire showed the reasons of the learners. Teaching material is originally a set of basic activities to do by learners to maximize their understanding and to construct their basic skills based on the learning achievement indicators to follow. However, based on the questionnaire result on question number two, learners did not consider the applied teaching materials were excellent because 1) the explanation and the reading were not interesting, 2) the information and the examples were limited, and 3) there was no new information. The findings were in line with Andari \& Sudarwati (2018), Snegurenko et al (2019), and Wardani et al (2020) that teaching materials should be interesting and provide rich and meaningful information for learners. The interview results with learners, labeled $\mathrm{AH}$, showed that he considered the examples were far from the reality they saw in real life (Interview result, 02/2021). A similar finding was also found from the other learners (Interview, 01/2021). This finding should be handled because non-actual or unreal examples on textbook could lead to misconception for the learners (Akbari, Sari, Siwi, \& Sri Rahayu, 2018; Ekowati, 2018; Fatimah, 2019; Hardi, 2019; Sujidin, Hanafi, \& Nuriadi, 2019; Wijayanti \& Putri, 2020).

Some learners, based on the questionnaire results, wanted accessible examples from their life. They expected the examples were accessible as they could do it by watching YouTube, reading comics, and watching drama online, etc (Interview, 01/2021). Thus, they preferred new things that could be accessed everywhere moreover during this pandemic. This finding was also in line with Alcaide et al (2020) L. Hakim (2020), Hidayati \& Fatmawati (2020), Jaramillo-Alcázar et al (2021), Rerung (2013), Rosenberg \& Lawson (2019). They found that accessible examples especially online facilitate learners to obtain and construct new knowledge and freed them from limited resources. Learners also needed teaching materials that could provide interaction, discussion, communication, and facility for new experience and information (Interview, 01/2021).

\section{The learners' information sources}

From the questionnaire, the third question item, the learners needed various information in the form of audio, videos, and figures. Studies by Kholis (2018), Kurniawati (2020), Masela \& Subekti (2020), and Putri et al (2021) showed that visual typed learners, they preferred these media because they could provide more meaningful information. This situation was the real part of learning with a scientific approach. The scientific approach motivates learners to be aware of the learning importance. Moreover, in this modern era, the learning needs and information could be obtained from various sources and packages.

Based on the interview with several learners, they admitted that they needed writing exercises with feedback and interesting guidelines (01/2021). Studies showed that feedback, especially for online learning, was important to engage learners in learning, motivate them, make them aware, and allow them to consciously construct knowledge (Alfehaid, Qotineh, Alsuhebany, Alharbi, \& Almodaimegh, 2018; Chaou et al., 2019; Dose, 2017; Ducasse \& Hill, 2019; Duhlicher, 2019; Espasa, Mayordomo, Guasch, \& Martinez-Melo, 2019; Ketonen, Nieminen, \& Hähkiöniemi, 2020; Ling \& Law, 2019; Tyrer, 2021). Some learners wanted the tutorial video to learn drama scriptwriting (01/2021). The other learners argued they needed a more interactive teaching material to facilitate them (01/2021). Heretofore, the teacher spent his time delivering the materials (interview, 01/2021). During this pandemic, the opportunity to provide exercise was also limited due to online material delivery (Interview, 01/2021). It indicated that learners needed unlimited teaching materials in terms of time. 
The learners' expectation toward the developed teaching materials

The fourth question was answered based on the learners' expectations toward the developed teaching materials. From the questionnaire, the learners wanted the teaching materials were not limited to textbooks. A learner expected the online learning during the pandemic was not only moving the offline class into an online class. He expected the class could habituate the learners with technology (Interview, 02/2021). The technologies were such as email, YouTube video upload, social media to publish work, etc (Interview, 01/2021). The learners were aware of digital literacy. Thus, teachers should have also developed digital-literacy-based teaching materials. Studies by Alfia et al (2020), Duriawati et al (2020), Fernanda et al (2020), Kumpulainen et al (2020), and Pradana et al (2020) showed that digital literacy could support the needs of $21^{\text {st }}$-century learners to compete in a global world.

Learners admitted to enjoying the learning via tutorial videos, articles on the Internet, social accounts of public figures, quotations, songs and audios, and online magazines (Interview, 01/2021). They expected the teaching materials to have similar functions to Wikipedia because it only needs one click to be re-directed to other information (Interview, 01/2021). Learners also wanted to perform their skills while learning. Some learners provided examples of their performances on Instagram, for example, photography (Interview, 01/2021). They were confident to show their skills and enjoyed the feedback shared by other Instagram users (Interview, 01/2021).

The findings showed that learners considered the current applied teaching materials were already excellent. However, most teaching materials were boring or not simple. The learners could not develop their skills. They were easily feeling bored and not attracted. They argued that the examples were far from the reality around them. They wanted accessible examples from their life, such as when they were watching YouTube, reading comics, and watching drama online. They required spaces to interact, discuss, and communicate. They needed facilities to work on the task, to draw attention, to motivate the learning, and to provide experience from new information. They expected new information that would be packaged in audio, videos, and attractive figures. Learners needed drama script exercise, feedback, exercise guideline, drama script tutorial video, and interactive teaching materials. They wanted to be habituated with the communication technologies by sending an email, uploading YouTube videos, and posting the works on social media. They needed quick and free access while constructing their knowledge and training their skills easily as if they used Wikipedia, Instagram, or other online media. From the results, the researchers would develop a teaching material with Moodle. Moodle, Modular Object-Oriented Dynamic Learning Environment, is computer software to build an e-learning web. It has features needed by educators and learners to promote web-based learning freely and transparently. It could be used and developed based on the users' needs.

\section{Conclusion}

The findings showed that the learners needed communication and technology-based teaching materials to support their needs of drama script writing skill training. Based on the learners' characteristics identification, they needed learning application to make the learning activities and to freely enrich the sources. They also needed interesting teaching materials that had many examples, provided writing exercises, the opportunity to interact, time to work the exercise, and space to perform. Therefore, this research proposed Moodle application as a learning material in the form of a Student Worksheet. The results of the learners' need analysis could be also used by other researchers to obtain the $21^{\text {st }}$-century learners' characteristics. The results of this research could be also followed up by developing a product to fulfill the learners' needs. 


\section{References}

Admadja, I. P., \& Marpanaji, E. (2016). Developing Learning Multimedia of Individual Practice in Fundamental Music Instrument for Smk Students in the Expertise of Karawitan. Jurnal Pendidikan Vokasi, 6(2), 173-183. https://doi.org/10.21831/jpv.v6i2.8107.

Aji, Y. N. W., Suwignyo, H., \& Maryaeni. (2017). Pengembangan Bahan Ajar Memerankan Drama Berbasis Legenda Untuk Kelas Vii. Jurnal Pendidikan: Teori, Penelitian, Dan Pengembangan, 2(9), 1168-1174.

Akbari, S., Sari, N. K., Siwi, D. A., \& Sri Rahayu, M. H. (2018). Design of teaching and learning materials based on the values of local heroic struggle in Sukoharjo. International Journal of Multicultural and Multireligious Understanding, 5(6), 28. https://doi.org/10.18415/ijmmu.v5i6.454.

Alcaide, T. C. H., Solis, M. H., \& Hontoria, J. F. (2020). Online learning tools in the era of m-learning: Utility and attitudes in accounting college students. Sustainability (Switzerland), 12(12). https://doi.org/10.3390/su12125171.

Alfehaid, L. S., Qotineh, A., Alsuhebany, N., Alharbi, S., \& Almodaimegh, H. (2018). The perceptions and attitudes of undergraduate healthcare science students of feedback: a qualitative study. Health Professions Education, 4(3), 186-197. https://doi.org/10.1016/j.hpe.2018.03.002.

Alfia, N., Sumardi, S., \& Kristina, D. (2020). Survival skills in digital era: an integration of digital literacy into EFL classroom. Indonesian Journal of EFL and Linguistics, 5(2), 435. https://doi.org/10.21462/ijefl.v5i2.307.

Amin, A. (2018). Pengembangan bahan ajar PAI pokok bahasan aspek akidah berbasis pembelajaran metafora dalam meningkatkan pemahaman konsep siswa SMPN 17 Kota Bengkulu. Manhaj: Jurnal Penelitian Dan Pengabdian Masyarakat, 3(1), 31. https://doi.org/10.29300/mjppm.v3i1.2342.

Andari, N., \& Sudarwati. (2018). Analisis buku ajar Marugoto: bahasa dan kebudayaan Jepang A1 ditinjau dari ranah kognitif taksonomi Bloom. JAPANEDU: Jurnal Pendidikan Dan Pengajaran Bahasa Jepang, 3(1), 24-37. https://doi.org/10.17509/japanedu.v3i1.10192.

Andrajati, N. H., Anis, M. B., \& Mahmudi, A. (2020). Development of online thematic teaching materials based on higher order thinking skills (HOTS) subtheme Wealth of Energy Sources in Indonesia. IJIS Edu: Indonesian Journal of Integrated Science Education, 2(2), 152. https://doi.org/10.29300/ijisedu.v2i2.3427.

Anh, D. T. N. (2019). EFL student's writing skills: challenges and remedies. IOSR Journal of Research \& Method in Education, 9(6), 74-84. https://doi.org/10.9790/73880906017484.

Asrowi, Hadaya, A., \& Hanif, M. (2019). The impact of using the interactive e-book on students' learning outcomes. International Journal of Instruction, 12(2), 709-722. https://doi.org/10.29333/iji.2019.12245a.

Bedagama, D. N., Rukmini, D., Anggani, D., \& Bharati, L. (2021). The Existence of Representational Meaning in Supporting Ideational Meaning in the Radio Communication On Board Texts in MarEng ${ }^{\mathrm{TM}}$ Learning Tool. English Education Journal, 11(1), 149-159.

Behnke, Y. (2018). The Palgrave Handbook of Textbook Studies. The Palgrave Handbook of Textbook Studies. https://doi.org/10.1057/978-1-137-53142-1.

Chaou, C. H., Chang, Y. C., Yu, S. R., Tseng, H. M., Hsiao, C. T., Wu, K. H., ... Ling, R. N. 
Y. (2019). Clinical learning in the context of uncertainty: A multi-center survey of emergency department residents' and attending physicians' perceptions of clinical feedback. BMC Medical Education, 19(1), 1-9. https://doi.org/10.1186/s12909-0191597-8.

Cintang, N. (2019). Pengembangan bahan ajar tematik berbasis scientific untuk siswa kelas IV SD tema tempat tinggalku sub teme keunikan daerah tempat tinggalku. Dinamika Jurnal Ilmiah Pendidikan Dasar, 10(2), 85-92. https://doi.org/10.30595/dinamika.v10i2.3892.

Dose, E. M. C. (2017). The importance of the feedback in distance education. Revista on Line de Política e Gestão Educacional, 21(3), 1565-1571. https://doi.org/10.22633/rpge.v21.n3.2017.10973.

Ducasse, A. M., \& Hill, K. (2019). Developing student feedback literacy using educational technology and the reflective feedback conversation. Practitioner Research in Higher Education, 12(1), 24-37. Retrieved from http://insight.cumbria.ac.uk/id/eprint/4574/.

Duhlicher, O. (2019). Providing effective feedback and correcting errors in the EFL classroom. Studia Universitatis Moldaviae, 5(5), 72-78. Retrieved from http://dspace.usm.md:8080/xmlui/handle/123456789/2327.

Duriawati, A. D., Wasliman, I., Mulyanto, A., \& Barlian, U. C. (2020). Implementation of literation based learning information technology (study at MTs Alkasyaf, Mts Nurul Huda, and MTs El-Bas Ciamis). International Journal of Nusantara Islam, 8(2), 240253. https://doi.org/10.15575/ijni.v8i2.11338.

Ekowati, K. (2018). The development of number teaching aids to minimize misconception of elementary school students in the Kupang city. AJES: Academic Journal of Education Science, 1(1), 42-45. https://doi.org/10.35508/ajes.v1i1.1266.

Espasa, A., Mayordomo, R. M., Guasch, T., \& Martinez-Melo, M. (2019). Does the type of feedback channel used in online learning environment matter? student' perception and impact on learning. Active Learning in Higher Education, 1-14. https://doi.org/10.1177\%2F1469787419891307.

Fatimah, N. (2019). Students' needs for academic writing at the English education department. English Language Teaching Educational Journal, 1(3), 161. https://doi.org/10.12928/eltej.v1i3.744.

Fernanda, F. F. H., Rahmawati, L. E., Putri, I. O., \& Nur'aini, R. (2020). Penerapan literasi digital SMP Neeri 20 Surakarta. Buletin Literasi Budaya Sekolah, 2(2), 141-148. https://doi.org/10.23917/blbs.v2i2.12842.

Hakim, L. (2020). Pemilihan platform media pembelajaran online pada masa New Normal. Justek: Jurnal Sains Dan Teknologi, 3(2), 27. https://doi.org/10.31764/justek.v3i2.3516.

Hakim, L. N., \& Wati, S. (2019). The use of lesson writer in developing English teaching materials for Vocational School Students. IDEAS: Journal on English Language Teaching and Learning, Linguistics and Literature, 7(2), 13-20. https://doi.org/10.24256/ideas.v7i2.996.

Hardi, A. (2019). Teacher perception on digital media fluency in English language teaching expectation and reality in Indonesian context. International Seminar and Annual Meeting BKS ..., 283-290.

Hidayati, F. N., \& Fatmawati, N. L. (2020). Peningkatan mutu sarana pendidikan melalui pengembangan self access library for English students (SALE). Jurnal Penjaminan Mutu, 6(1), 15-22. 
Jaramillo-Alcázar, A., Venegas, E., Criollo-C, S., \& Luján-Mora, S. (2021). An approach to accessible serious games for people with dyslexia. Sustainability (Switzerland), 13(5), 1-17. https://doi.org/10.3390/su13052507.

Juniastuti, A., Falatehan, A. F., \& Muljono, P. (2018). Strategi peningkatan kualitas konten diklat berbasis E-learning pada pusdiklat anggaran dan perbendaharaan. Jurnal Manajemen Pembangunan Daerah, 10(2).

Ketonen, L., Nieminen, P., \& Hähkiöniemi, M. (2020). The development of secondary students' feedback literacy: Peer assessment as an intervention. Journal of Educational Research, 113(6), 407-417. https://doi.org/10.1080/00220671.2020.1835794.

Khaerudin, D., Kusmana, S., \& Khaerudin, I. R. (2019). Pengembangan Bahan Ajar Menulis Drama Berdasarkan Pengalaman Pengarang Sebagai Bahan Ajar Drama Di Smp / Mts. Jurnal Tuturan, 8(2), 86-95. https://doi.org/10.33603/jt.v8i2.2867.

Kholis, A. (2018). The effectiveness of using video and pictures in teaching writing hortatory exposition text. LingTera, 5(2), 189-198. https://doi.org/10.21831/lt.v5i2.15490.

Kumpulainen, K., Sairanen, H., \& Nordström, A. (2020). Young children's digital literacy practices in the sociocultural contexts of their homes. Journal of Early Childhood Literacy, 20(3), 472-499. https://doi.org/10.1177/1468798420925116.

Kurniawati, N. (2020). Creating low-cost animation video using online platform: a learning media user review. Jurnal Pendidikan Kedokteran Indonesia: The Indonesian Journal of Medical Education, 9(1), 26. https://doi.org/10.22146/jpki.53166.

Ling, Y.-L., \& Law, H. S. G. (2019). Feedback environment in the workplace: implications for intrinsic motivation. Asian Journal of Social Science Research, 2(1).

Masela, M., \& Subekti, A. S. (2020). Indonesian university students' visual learning style: learners' and teachers' perspectives. ETERNAL (English, Teaching, Learning, and Research Journal), 6(2), 259. https://doi.org/10.24252/eternal.v62.2020.a6.

Mudasih, I., Tjipto, S. W., \& Susanti. (2020). The effect of financial literacy, digital literacy, and entrepreneurial learning outcome on entrepreneur behavior of students at SMK Negeri 1 Surabaya. Technium Social Sciences Journal, 6.

Murti, S., \& Muhtadin. (2019). Pengembangan LKS Menulis Naskah Drama Siswa Kelas VIII SMP se-Kecamatan Tugumulyo keaktifan siswa sehingga kurang dapat mengembangkan gagasan atau idenya dalam. Prosiding Seminar Nasional Bulan Bahasa (Semiba), 256-264.

Pradana, L. N., Sholikhah, O. H., Maharani, S., \& Kholid, M. N. (2020). Virtual mathematics kits (VMK): Connecting digital media to mathematical literacy. International Journal of Emerging Technologies in Learning, (3), 234-241. https://doi.org/10.3991/ijet.v15i03.11674.

Putri, F., Cahyani, K., Rukmini, D., \& Fitriati, S. W. (2021). The Role of Representational Meaning of Images in Supporting Ideational Meaning in English in Mind : Students ' Book. English Education Journal, 11(1), 97-104.

Reddy, D. S., \& Ramesh, L. S. R. C. . (2020). Pros and cons of E-learning by children in rural areas during lockdown sitaution and ways to empower it. International Journal of Innovative Technology and Research, 7-9.

Rerung, M. K. T. (2013). Perceptions on online language teaching pedagogy. Journal of Chemical Information and Modeling, 53(9), 1689-1699. https://doi.org/10.31316/eltics.v6i1.1084.

Rosenberg, J. M., \& Lawson, M. A. (2019). An investigation of students' use of a 
computational science simulation in an online high school physics class. Education Sciences, 9(1), 1-19. https://doi.org/10.3390/educsci9010049.

Rozalina. (2020). Manajemen pembelajaran digital melalui aplikasi youtube. Seminar Nasional Pendidikan PPs Universitas PGRI Palembang 2, 684-694.

Setyowati, L., \& Sukmawan, S. (2019). Authentic materials for teaching writing: A critical look. International Journal of Language Education, 3(2), 68-77. https://doi.org/10.26858/ijole.v3i2.9609.

Snegurenko, A. P., Sosnovsky, S. A., Novikova, S. V., Yakhina, R. R., Valitova, N. L., \& Kremleva, E. S. (2019). Using e-learning tools to enhance students-mathematicians' competences in the context of international academic mobility programmes. Integration of Education, 23(1), 8-22. https://doi.org/10.15507/19919468.094.023.201901.008-022.

Sujidin, S., Hanafi, N., \& Nuriadi, N. (2019). The designing syllabus in teaching writing narrative text Putri Manalika at Central Lombok. International Journal of Multicultural and Multireligious Understanding, 6(2), 371. https://doi.org/10.18415/ijmmu.v6i2.681.

Suryani, I., \& Rasdawita. (2018). Pengembangan Bahan Ajar Menulis Naskah Drama Berbasis Pendekatan Kontekstual di FKIP Universitas Jambi PENDAHULUAN Peraturan Rektor Universitas Jambi Nomor 02 tahun 2017 , dosen sebagai ilmuan memiliki tugas mengembangkan suatu cabang ilmu pengetahuan dan. Pena, Jurnal Pendidikn Bahasa Dan Sastra, 8(1), 80-92. https://doi.org/10.22437/pena.v8i1.6565.

Tyrer, C. (2021). The voice, text, and the visual as semiotic companions: an analysis of the materiality and meaning potential of multimodal screen feedback. Education and Information Technologies. https://doi.org/10.1007/s10639-021-10455-w.

Uba, S. Y., \& Souidi, N. M. (2020). Students' writing difficulties in English for business classes in Dhofar University, Oman. International Journal of Higher Education, 9(3), 86-97. https://doi.org/10.5430/ijhe.v9n3p86.

Wardani, P. T., Alwi, M., \& Hakim, A. R. (2020). Pengembangan bahan ajar IPA kelas V Sekolah Dasar menggunakan multimedia interaktif berbantuan animasi. Prima Magistra: Jurnal Ilmiah Kependidikan, 1(85), 191-198. https://doi.org/10.37478/jpm.v1i2.658.

Wijayanti, R., \& Putri, A. (2020). Pengembangan modul statistika matematika untuk meningkatkan hasil belajar mahasiswa (studi kasus di IKIP Budi Utomo Malang). Media Bina Ilmiah, 15(3), 4281-4286. https://doi.org/10.33758/mbi.v15i3.875.

Yogiyatno, W., \& Sofyan, H. (2013). Pengembangan multimedia interaktif kompetensi dasar mengoperasikan software basis data untuk SMK Negeri 1 Seyegan. Jurnal Pendidikan Vokasi, 3(3), 391-404. https://doi.org/10.21831/jpv.v3i3.1851.

Zagorskis, V., Kapenieks, A., \& Gorbunovs, A. (2019). Emotions identification utilizing periodic handwriting on mobile surfaces. Periodicals of Engineering and Natural Sciences, 7(1), 228-237. https://doi.org/10.21533/pen.v7i1.355.

Степанов, O., \& Stepanov, O. (2020). Usage of social networking sites by studentsVeterinarians who study operative surgery. Педагогічний Дискурс, (28), 32-38. https://doi.org/10.31475/ped.dys.2020.28.04. 